\title{
Under Ground Treasure: A Preliminary Inquiry into the Ecology and Distribution of Zambian Truffles
}

\author{
Stanford M Siachoono ${ }^{1}$, Obote Shakachite ${ }^{1}$, Alexinah M Muyenga ${ }^{1} \&$ Justice Bwalya $^{1}$ \\ ${ }^{1}$ Copperbelt University, Jambo Drive, Kitwe, Zambia \\ Correspondence: Stanford M Siachoono, Copperbelt University, Jambo Drive, Kitwe, Zambia. E-mail: \\ Stanford.siachoono@cbu.ac.zm
}

Received: November 10,2015 Accepted: November 19, 2015 Online Published: December 26, 2015

doi:10.5539/ijb.v8n2p1 URL: http://dx.doi.org/10.5539/ijb.v8n2p1

\begin{abstract}
Zambian truffles, (believed to belong to the genus Terfezia because of its proximity to the Kalahari truffles), with a native Lozi name as Zoondwe ( $p$ ) in Western province of Zambia, have been on the diet of many local inhabitants for many years. They are collected or hunted at the end of the rainy season between early April and early July each year. Very little is known of the Zambian truffles scientifically apart from the local ethno mycological knowledge. The present work is a preliminary study carried out to understand their ecology, plant interaction and distribution including the soil $\mathrm{pH}$ and the weather conditions.

The second revelation was the occurrence of a similar truffle species which the locals call simbulukutu. It is a bitter relative of the actual truffles that the locals eat. Despite the bitterness, the locals eat it, with special preparation, in hard times.
\end{abstract}

Keywords: truffles, mycorrhizae, hypogenous fungi, ascomycetes

\section{Introduction}

Truffles are eaten worldwide as a delicacy and fetch a higher price than the ordinary mushrooms depending on the species on the market (Luard, 2006). The strong aromatic scent gives them a unique culinary identity to the gourmet lovers. The interest in Zambian truffles in this study is therefore two fold; one is to study their ecology and distribution and understand their ethno mycology and how it affects the local communities' livelihood; secondly to study their identity and their association with local plants so as to assess their potential for domestication like other truffle species that have been domesticated elsewhere (Trappe et al., 2009).

Zambian truffles occupy a special place in the taxonomy of mycology; however, they have not yet been scientifically identified yet. Their identity has remained at the ethno-mycological level with local people just calling them zoonde and harvesting them on an annual basis as a source of food and income. This study emanates from an earlier unpublished work undertaken by an MBA student at the Copperbelt University who looked at marketing indigenous products. (Muyenga, 2012)

This article is a review communication on the Zambian truffle as understood from an ethno mycological perspective and the given scientific description of what makes a truffle. So far there is no scientific record and identity of the Zambian truffle occurrence in the country. This article is a pilot study of the Zambian truffles and is restricted to their ecology and ethno mycology and lays ground for future studies in their taxonomic and nutrition studies.

\section{Study Site}

This study was carried out in Mongu and Senanga Districts in the Western Province of Zambia, between April and June in 2014 and 2015 truffle seasons each year. Senanga and Mongu lie on latitudes $15^{\circ}$ and $16^{\circ} \mathrm{S}$ and longitudes $22^{\circ}$ and $24^{\circ} \mathrm{E}$ in the western Zambia. Both locations form a large part of the Zambezi plains drainage system (Figure 1). The Zambezi River cuts its way forming a large flood plain before narrowing its course downstream towards the border with Namibia and Botswana borders.

This study was by no means an exhaustive survey of Zambian truffles. The areas visited were as a result of the limitations on resources. The area that supports the truffles is probably wider than the one visited. The truffle 
distribution limits are yet to be established through visits to areas beyond Mongu that have the same Kalahari sands and vegetation types that are associated with truffles in the known areas of Mongu and Senanga districts.

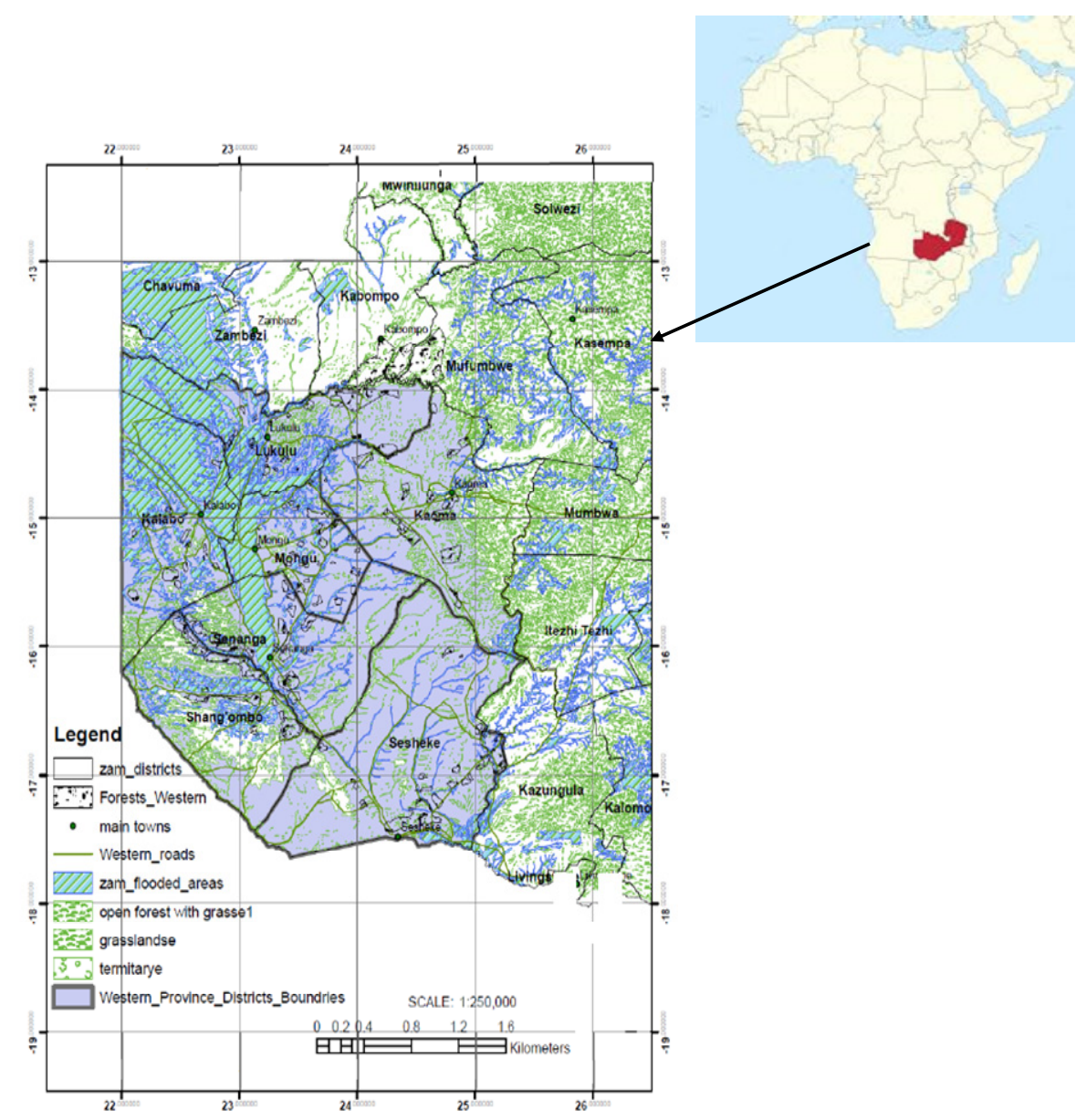

Figure 1. Map of Western Zambia (source: Forest Department, Mongu)

\subsection{Climate}

The Zambian climate discipline is easily followed from the three agro- ecological zones, namely zone I, II and III used to divide the country. Zone II is further divided into IIa and IIb where Mongu and part of Senanga fall. This classification though intended for agricultural guidance assists one to make an on the spot analysis of the rainfall and temperature regimes.

Senanga forms the boundary between zone I and IIb, both that receive medium rainfall per annum (Figure2).
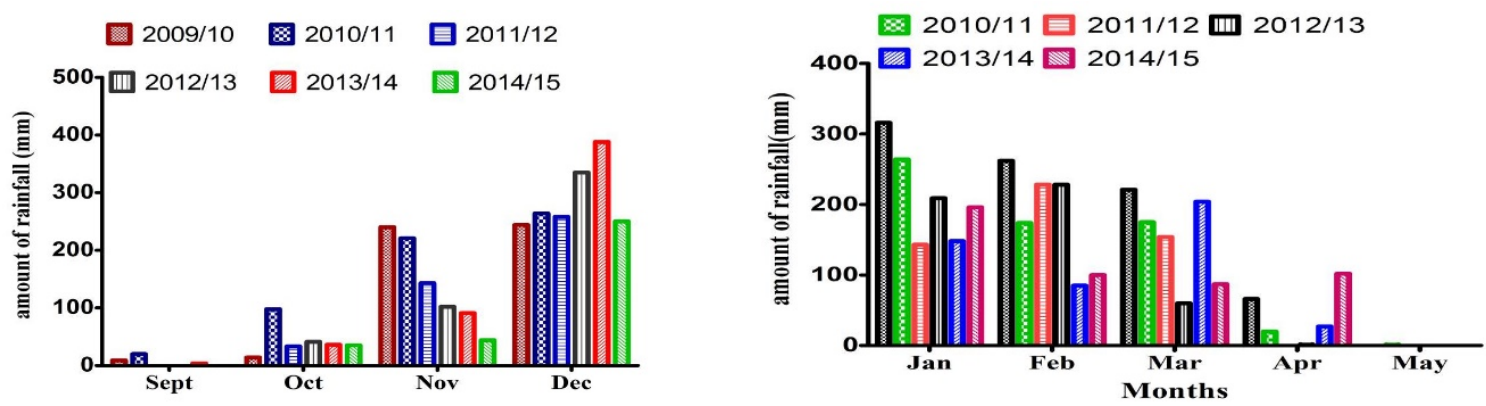

Figure 2. Rainfall patterns 
The soils in Western Zambia are mainly Kalahari sands whose evolutionary period appears around 1.8 million years ago in the quaternary and tertiary systems. The texture and colour of soils is loose dark grey (Figure 3 ) whose $\mathrm{pH}$ is around 6.3. A test for a number of trace elements was conducted using methods of soil analysis prescribed by Page (1982). Results showed high levels of potassium and lead in milligrams per liter (see Figure 4)

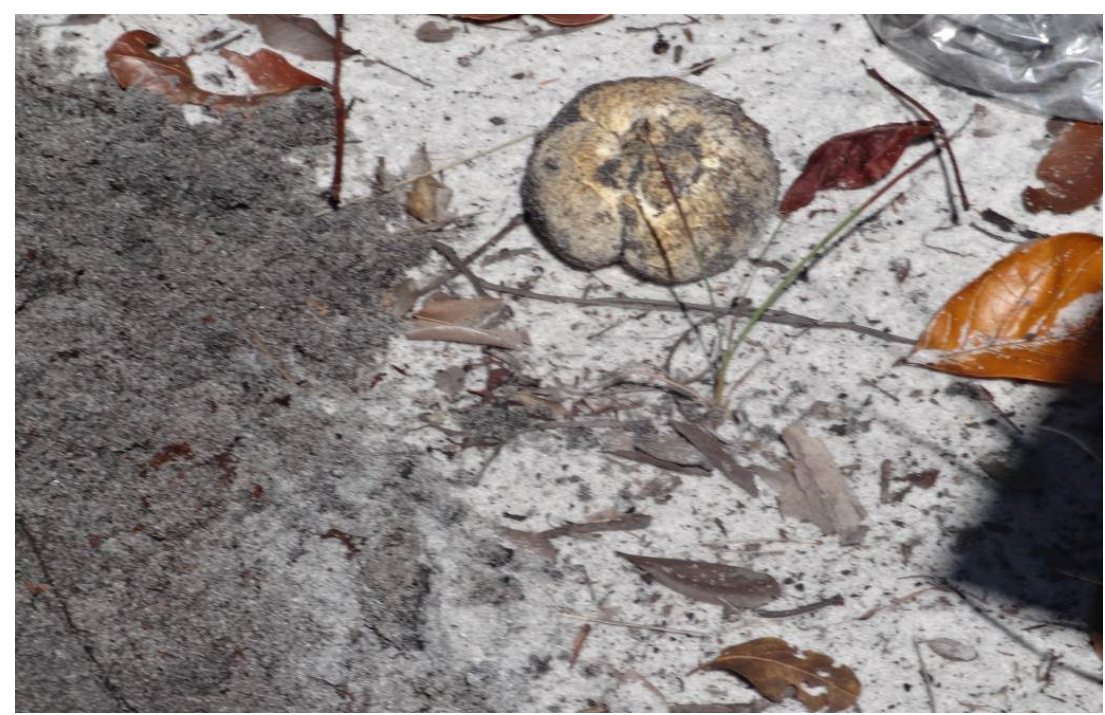

Figure 3. Harvested Truffle. Photo:s
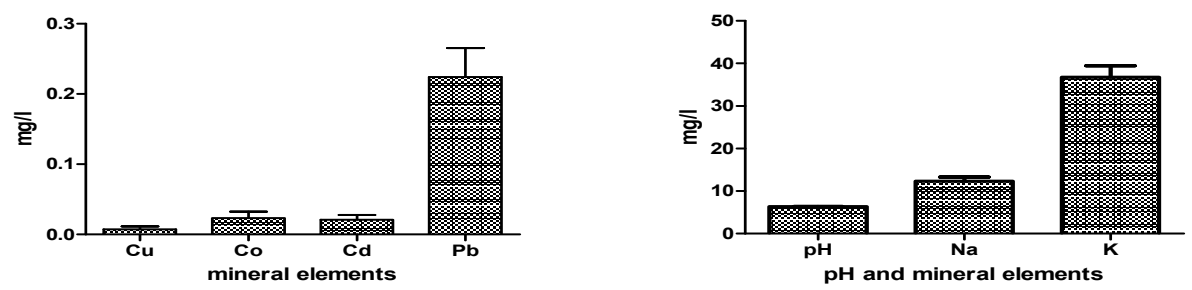

Figure 4. Soil Mineral Elements and $\mathrm{pH}$

\subsection{The Zambian Truffle Ecology}

Truffles are a diverse hypogenous group of mushrooms and are found in all continents in the world. They are so diverse that in North America the forests of North Pacific Northwest records more than 350 species in 35 genera (Trappe et al., 2009).Truffles have been studied for more than a century. Vittadini (cited in Trappe et al., 2009) gave a more elaborate description in 1881 and was the first to recognize the importance of mycorrhizae to the nutrition of the host tree species (Trappe et al., 2009).

The survival of truffles worldwide lies in their ability to form the mycorrhiza with the roots of the host trees; in return the trees acquire the nutrients that are essential to their survival. The two hence have evolved together with this symbiotic relationship (Trappe et al., 2009. They have adapted to being underground fruiting fungi probably as an adaptation strategy to escape fire and frosty period's temperatures on the ground surface.

The Zambian truffles are found mainly in the Kalahari sands in western province of Zambia where the vegetation is mainly dominated by the commercial timber producing Baikiaea woodlands. The hardwood timber species include the Guibourtia coloesperma (red wood) and, Pterocarpus angolensis (mukwa) trees that form the bulk of the forest species that are associated with the Zambian truffles. The forests are well drained with dambos and plains that drain the water into the adjacent Zambezi plains.

Storrs (1995) gives an elaborate account of the trees of Zambia. The timber producing forests of the study area have a variety of shrubs and other herbaceous bushes in the truffle growing areas that may be critical to the truffle mycorrhiza association and hence their survival. 
Table 1. Tree species associated with the Zambian truffles

\begin{tabular}{lcl}
\hline Local name (Lozi) and English Common name & (Species)Scientific name \\
\hline Muzauli & Red wood & Guibourtia coloesperma \\
Musese & Wild syringa & Burkea africana \\
mubombo & & Brachystigia spp \\
Muntentenya & & Ochna pulchra \\
Mulutulwa & Wild plum & Ximenia caffra \\
Mutembo & Yellow wood & Monotes africanus \\
Munyonga & & Ekebergia capensis \\
Mubako & & Erthropyhlum africanum \\
Isunde & & Baphia massaiensis \\
Mukwe & & Cryptosepellum exfoliatum \\
Mufula & Bush willow & Combretum molle \\
Musongolo & & Diospyros batocana \\
Mukwa & & Pterocarpus angolensis \\
\hline
\end{tabular}

The close relativesof the Zambian truffles are the Kalahari truffles (kalahari tuber pfelii spp.) found in the neighboring Namibia south of western province in Zambia. This truffle species has been used by the Khoisan or the San people of the Kalahari in Southern Africa for many years. The discovery of two other truffle genera in Namibia and Botswana and third from the Northern Cape West of Kimberly in South Africa each represented by a single species (Trappe et al., 2008) adds to the prospect that Zambia could probably have a new genus and a new species given the fact that the ecological conditions that include rainfall, soil $\mathrm{pH}$ and vegetation greatly vary in these locations.

\section{Truffle Morphology, Systematics}

\subsection{Morphology}

The Zambian truffles' morphology seems to suggest that they belong to the ascomycetes group implying that they produce their spores in the sac-shaped structure that forms their basic appearance. The three truffle species found in the Southern Africa discussed by Trappe et al. (2008) are said to belong to the family Pezizaceae. Laessoe and Hansen (2007) state that this group was at one time treated as Tuberales. The group has seven families, namely Pezizaceae, Pyronematatceae, Geneaceae, Helvellaceae, Balsamiaceae, Terfeziaceae and Tuberaceae with fifteen genera in total. One can speculate that the Zambian truffles belong to the family Pezizaceae, but it leaves a question mark on their genera and species. One route would be to carry out a molecular investigation in relation to their relatives in the neighbouring Namibia and rule out the similarities or differences. Thereafter attempt to isolate them as separate genus and species.

Truffles are said to have been derived from mushroom ancestors in the evolutionary pathway. Morphologically they exhibit a vestigial stem that is not enough to lift them out of the ground and a cap that does not open to expose the gills. This vestigial stem may be further lost in some species (Trappe et al., 2009). In this way truffles can be identified through such visual attributes by the inquiring person.

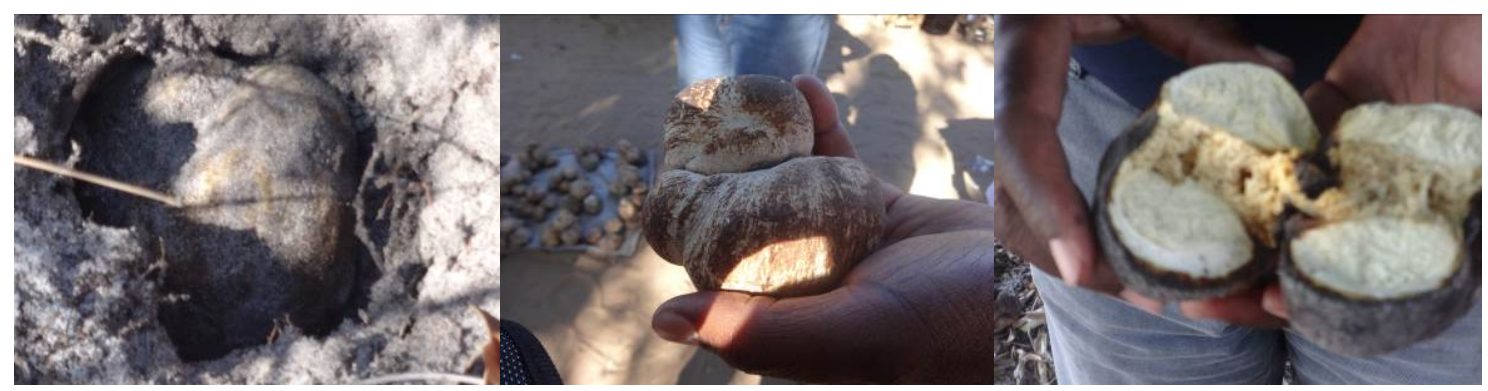

Figure 5. Exposed Truffles and a cut truffle. Photos:s 


\subsection{Taxonomy}

Truffle taxonomic studies have been studied since Vittadini made an elaborate description of truffles in 1881 (Trappe et al., 2008). However, taxonomic studies keep revealing new knowledge in mycology and their systematics in general. For example, molecular studies on the neighboring truffle species in Namibia, that was referred to earlier as Terfezia pfelii which until recently has been treated within Mediterranean genus Terfezia for a long time. This has been demonstrated as a new genus namely Kalaharituber pfeilii through molecular phylogenic techniques (Ferdman et al., 2005).

\subsection{Mycophagy and Spore Dispersal}

Truffles anywhere in the world do provide food to a host of forest animals. They owe this relationship to the odor that they produce as they mature. The odor attracts animals that dig them up and eat them. The spores survive the animal digestive system and are later dispersed as spores elsewhere through fecal droppings (Trappe and Claridge 2005).Zambian animal spore dispersers are not clearly identified. The local people spoken to in the study area all suggest that the Common Duiker (Sylvicapra grimmia) and scrub hares (Lepus saxatilis) may be involved in the mycophagy of the Zambian truffles on account of the foot prints that are found in the truffle areas. Trappe et al. (2008) indicate that in the case of Kalahari truffles very little is also recorded but note that Mills (1990) observed a brown hyena (Hyaena brunnea) digging and eating truffles. Others include meerkats (Suricata suricatta).

\subsection{Ethno Mycology}

The native name for the Zambian truffle is soonde(s) and zoondwe (p). The areas where they are harvested are called myondwe by the local people. Its bitter relative is called simbulukutu(s). It is only eaten in desperate times and situations. Truffle hunting is usually done by men and women of the younger generation who search for truffles in the identified myondwe productive forests. Hunting starts in early April soon after the rainy season. Truffle hunters use a sharp pointed stick to prod the ground for truffles. The presence of a truffle produces a unique echo and the find is made and the truffle fruit body is dug out by hands or sticks to a $20-30 \mathrm{~cm}$ below ground. Hunters have specialized in the resulting echo sound in the hunting process from the poking of the ground. There is usually one truffle per find but it is possible to find more. It takes some training for one to be able to master truffle hunting this way. If the bitter truffle is located it is possible to have more than one fruit in one hole.

The hunting techniques change in May and June as the ground gets drier. The presence of truffle fruits is located by observing cracks on the ground.

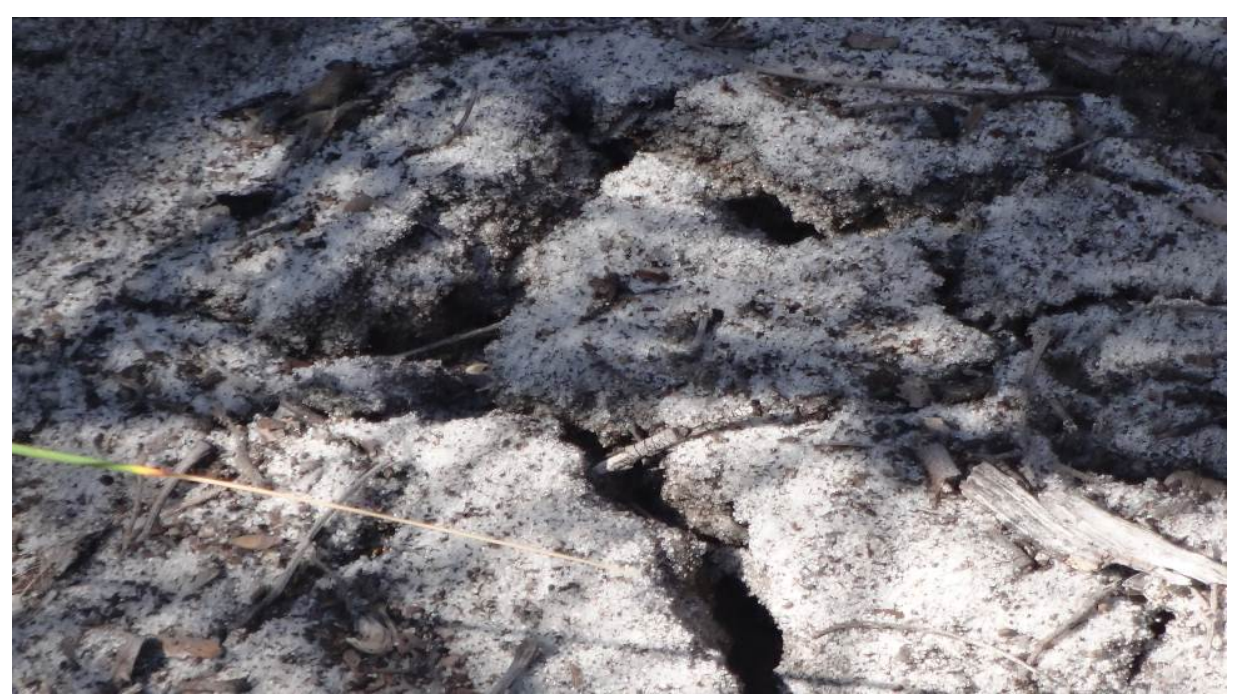

Figure 6 . The truffle presence is indicated by the cracked ground 


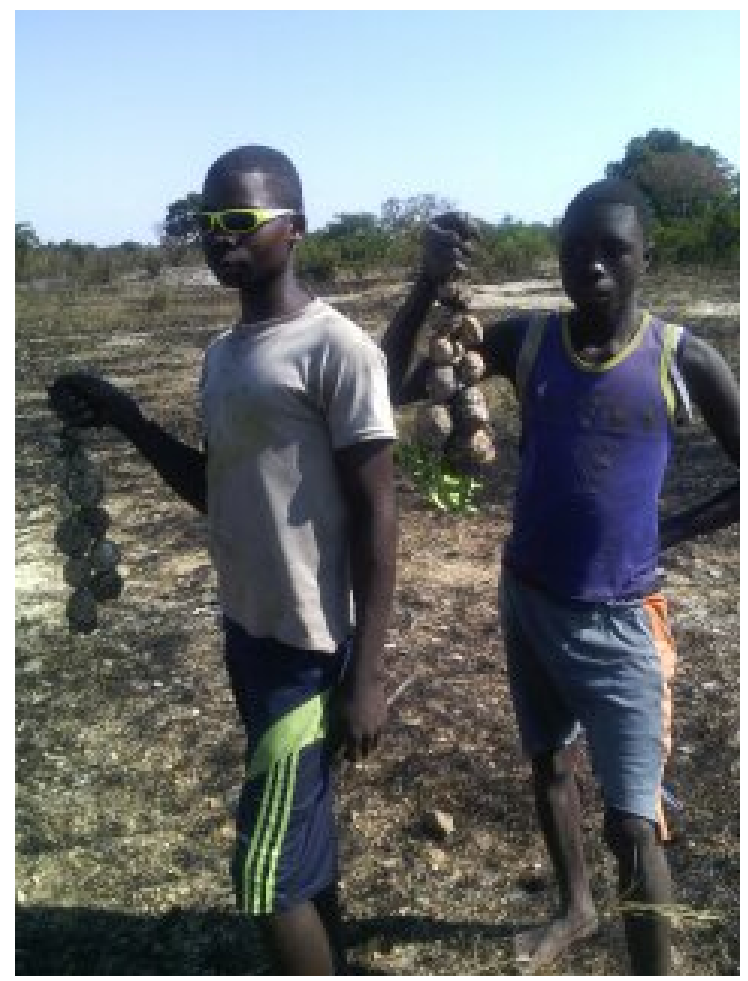

Figure 7. Successful truffle collectors selling their truffles by the roadside

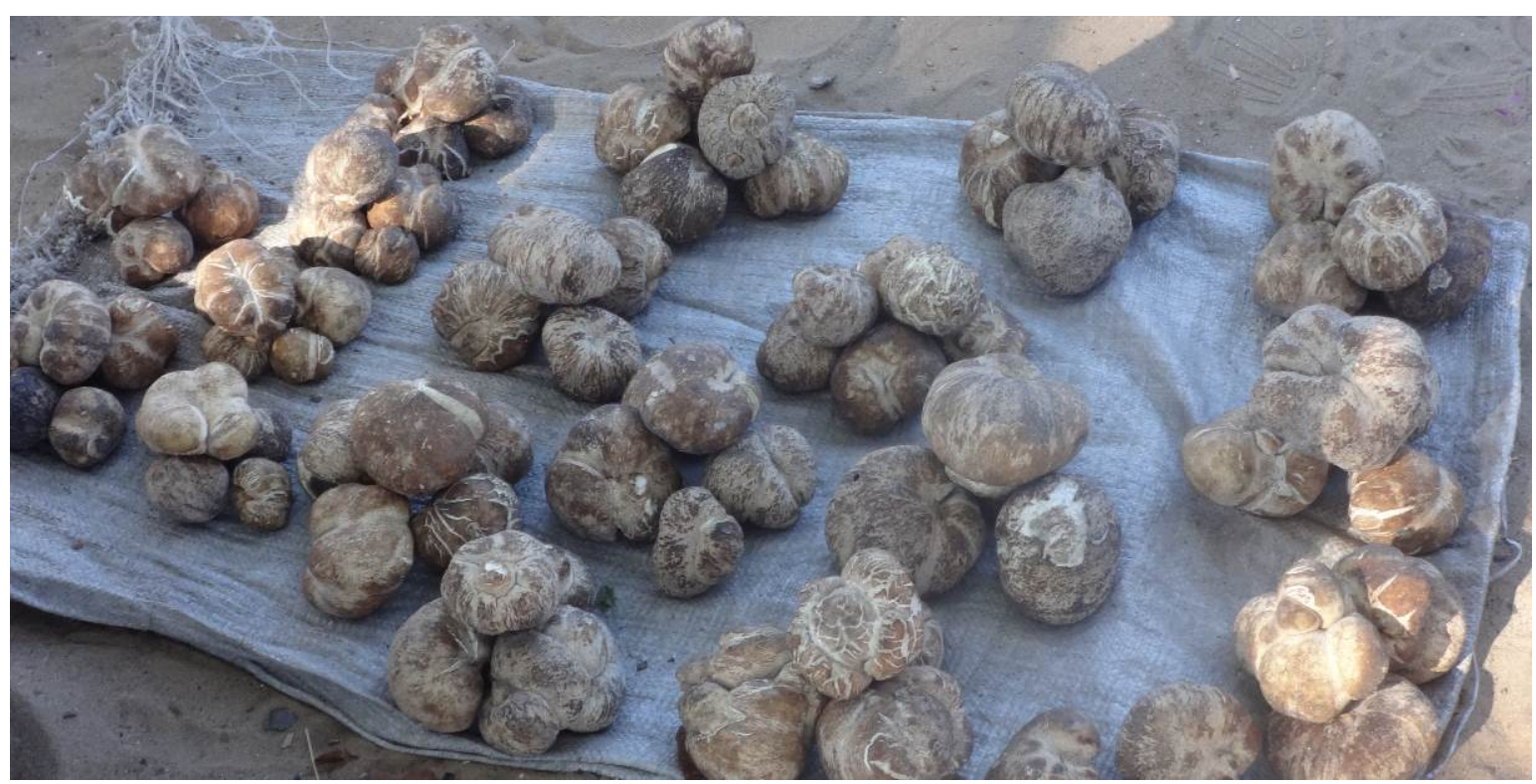

Figure 8.Truffles on sale in Senanga market

After collecting, the truffles are ready for sale mainly at the market. The sale is usually apportioned into small heaps at the market or by the road side and sell for just below a US\$ equivalent in the Zambian Kwacha. Truffles can stay fresh for up to seven days after being collected from the forest. This gives them a chance to be transported to some distance before they can go bad and deteriorate. 


\section{Discussion}

Zambian fungi have been documented by earlier workers. Piearce (1981) produced the first account of Zambian edible mushrooms. The information was based on the various discussions with local people and the importance of mushrooms in people's diet.

Similarly Harkonen et al. (2015) discuss the general classification of various Zambian fungi. The absence of truffles in their classification confirms the need for their taxonomic identity so as to make them part of the fungi found in Zambia.

The presence and occurrence of truffles in Western Zambia conforms to the notion or view that our biodiversity has not been fully understood because we still have species that need to be identified. People in Western Zambia have been exploiting truffles for several years, however they still remain unidentified by the scientific community. In this lack of knowledge and exposure lies the untapped food resources with a potential to be a resource base for raw materials for the nanotechnology industries such as nutritional additives to food processing and may hold an economic position in the wider truffle market. This also poses a great question on land use that has the potential to destroy the productive habitats for the Zambian truffles due to ignorance.

Truffles in Zambia have the potential for export and can compete with their European truffles counterparts. This will result in improved economic returns for the rural households that live close to the truffles areas.

Apart from the direct harvest, truffles have been proved to be easy to domesticate implying that they can be grown on a commercial basis on a truffle farm. To be able to achieve this there is a dire need for sound ecological and biological knowledge and the development of market structures that will give improved returns.

\section{Conclusion}

This study was a preliminary investigation into the occurrence of Zambian truffles in Western Zambia. It is not conclusive as the area visited was limited to a small place where truffles are harvested and sold as food at the market and the harvesting techniques are well developed by the local people. The investigation as to their occurrence should be extended to other areas in the country with similar vegetation, rainfall and soil types.

The Zambian truffles here also lack a scientific identity for them to be known to the rest of the scientific world. There is need for taxonomic investigation so as to establish their genus and species names. At the moment one can only speculate that they could be in the same genus as the Namibian truffle species. Their mycorrhiza association with plant species is also important aspect of knowledge that is needed to be investigated. Like all fungi they are heterotrophic in their nutrition, in that they decompose organic molecules that are originally built up by plants by secreting enzymes in their surroundings and thereby absorbing the dissolved organic molecules into their cells. In this case the trees, shrubs and plants that are specific to the association with truffles. The general taxonomy on the tree species that occur in the myondwe the truffle productive areas is well known and taxonomically identifiable. However there is a taxonomic knowledge gap in that other shrubs and plants are not well known. These may be the ones that play an important symbiotic relationship with the truffles.

Furthermore there is need to investigate their nutrition content so that they have value based on their nutrition and may be this should be done as a comparative study with other mushrooms in the country. This will be a worthwhile effort as truffles seem to fetch a higher price on the market especially European varieties for some unknown reasons perhaps owing to their being rare to find than ordinary mushrooms.

\section{Acknowledgements}

The authors would like to thank all the individuals who supported our work. The Copperbelt University, especially the staff in the School of Business Studies and the School of Natural Resources. Special thanks to Felix Chileshe, soil science Technician for the analysis of soils from the study area. The staff at the Copperbelt University Environmental Laboratory and our colleague Chester Kalinda for his help with the graphics. Dr Lackson Chama and Dr Royd Vinya for their guidance in the preparation of the manuscript

The Forest Department staff in Mongu for their unfailing support during our field work. Special thanks go to Mr. C Niamwiza and his staff Henry Mwale, Dominic Makole, and Douglas Chimbau. Special thanks to Humphrey M Sande for the cartographic drawing of the map of the study area. We also wish to thank Mr. Innocent Monde of the Meteorological Department for providing us with the weather data for Mongu and Senanga area.

Further, the authors are indebted to Dr. Maliti Biemba, Dr. Patricia Kamanga, Dr. Chanda Shikaputo Dr. Bruce Mwiya and Mr. Mwansa Chabala for their invaluable support and guidance throughout the study. We also are grateful to Prof. Frank Tailoka for his contributions towards this research. 


\section{References}

Ferdman, Y., Aviram, S., Roth-Bejerano, N., Trappe, J. M., \& Kagan-Zur, V. (2005). Phylogenetic studies of Terfezia pfeilii and Choiromyces echinulatus (Pezizales) support new genera for southern African truffles: Kalaharituber and Eremiomyces. Mycological research, 109(02), 237-245.

Gioacchini, A. M., Menotta, M., Bertini, L., Rossi, I., Zeppa, S., Zambonelli, A., ... \& Stocchi, V. (2005). Solid phase microextraction gas chromatography/mass spectrometry: a new method for species identification of truffles. Rapid Communications in Mass Spectrometry, 19(17), 2365-2370.

Harkonen, M., Niemela, T., Mbindo, K., Kotiranta, H., \& Piearce, G. D. (2015). Zambian Mushrooms and mycology. Finish Museum of Natural History (Botany Unit) University of Helsinki, Helsinki. Finland. Helsinki 2015.

Laessoe, T., \& Hansen, K. (2007). Truffle trouble: What happened to the tuberales (pp. 1075-1099)? British Mycological Society.

Luard, E. (2006). Truffles. Frances Lincoln Edition

Mills, M. G. L. (1990). Kalahari Hyenas. New Jersey: The Blackburn Press Caldwell.

Molina, R., Luoma, D. L., Cázares, E., Pilz, D., Smith, J. E., Castellano, M. A., ... \& Trappe, M. J. (2009). Diversity, ecology, and conservation of truffle fungi in forests of the Pacific Northwest (Vol. 772). US Department of Agriculture, Forest Service, Pacific Northwest Research Station.

Muyenga, A. M (2012). Marketing of Zambian Indigenous Products. Kitwe: MBA Dissertation Copperbelt University. (unpublished)

Page, A. L. (1982). Methods of Soil Analysis Part 2 Chemical and microbiological Properties (2nd ed.). American Society of Agronomy.

Piearce, D. G. (1981). An introduction to Zambia's wild mushrooms and how to use them. Forest Department (Ndola, Zambia).

Storrs, A. E. G. (1995). Know Your Trees, Some of the common trees found in Zambia. Zambia: Forest Department.

Trappe, J. M., \& Castellano, M. A. (1991). Keys to the genera of truffles (Ascomycetes). McIlvanea, 10, 47-65.

Trappe, J. M., \& Claridge, A. W. (2005). Hypogenous fungi: Evolution of reproductive and dispersal strategies through interactions with animals and mycorrhizal plants. In J. Dighton, J. M. White, P. Oudemans (Eds.), The fungal community-Its organization and role in the ecosystems $3^{\text {rd }}$ Boca Baton FL Taylor and Francis (pp. 613-623).

Trappe, J. M., Claridge, A. W., \& Kagan-Zur, V. (2014). Ecology and Distribution of Desert Truffles in the Kalahari of Southern Africa. In Desert Truffles (pp. 193-202). Springer Berlin Heidelberg.

Trappe, J. M., Claridge, A. W., Arora, D., \& Smit, W. A. (2008). Desert truffles of the African Kalahari: ecology, ethnomycology, and taxonomy. Economic botany, 62(3), 521-529.

\section{Copyrights}

Copyright for this article is retained by the author(s), with first publication rights granted to the journal.

This is an open-access article distributed under the terms and conditions of the Creative Commons Attribution license (http://creativecommons.org/licenses/by/3.0/). 